\title{
ANTHRIBIDAE FROM THE MALAY PENINSULA
}

\author{
BY DR. KARL JORDAN
}

THE specimens which form the subject of this paper were submitted to me for identification by Mr. H. M. Pendlebury, of the Federated Malay States Museum at Selangor, and have been returned to that institute with the exception of the types of the new forms and some duplicate specimens. As a large number of species are already known from the Malay Peninsula, particularly from Perak, I was surprised to find some large and conspicuous new forms in the collection. The material collected by Mr. Pendlebury is very carefully labelled, and, since we know so very little about the time of appearance, altitude, etc., of exotic Anthribidae, the data given on the labels are well worth publishing. Besides the species mentioned in this paper there are a few others in the collection which it is advisable to omit, as the identifications are not beyond doubt or too difficult to attempt with single specimens of obscure species.

\section{Eugigas goliathus Thoms. (1857).}

Perak: Batang Pedang, 1,800 ft., vi.1923 (H. M. Pendlebury), 1 ․We have this species from Java, Nias, Sumatra, and Borneo.

\section{Meganthribus atopus stellatus subsp. nov.}

+. Niger, supra et infra manifestis guttis albis notatus.

Long. $25 \mathrm{~mm}$. (cap. excl.).

Selangor: Gombak valley, viii. 1922 (H.P.M.), 1 \&, type.

Black, covered with a very short olivaceous pubescence, pronotum with shallow punctures at the sides of which there is a small granule. The white spots correspond to those of $M$. atopus atopus Jord. (1913) from Menado. On pronotum two at apex, an elongate one in middle, two on each side and a minute one on each side a little before the central spot, a white basal marginal border broken up into four transverse spots ; scutellum also white; on elytra a sutural spot at scutellum, sutural and alternate interspaces with black and white spots, the black spots inconspicuous; on underside an elongate spot anteriorly above forecoxa and three small spots at carina, on mesosternum a lateral spot on neck of segment and a border along hindside of mesepimerum, two spots on metasternum and a dash on metepisternum, intercoxal process of metasternum and partially also all coxae white; on abdomen a limbal and a submedian row on segments 1 to 4 . Indications of other spots here and there above and below. Antenna, tibiae, and tarsi black. Pygidium a little shorter than basally broad.

In a second specimen (), from Perak, Taiping, the pronotum has no punctures, only small granules, the pygidium is as long as broad, and the tarsal segments 1 and 2 are white proximally, in hindtarsus the first segment to near apex.

3. Meganthribus nubilus Jord. (1898).

Selangor, vii.1914, viii.1915, 2 우.—Peninsular Siam : Nakon Sri Tamarat, Khao Ram, 750 ft., ii. 1922 (H. M. Pendlebury), 1 ô. 
4. Mecotropis marmoreus Jord. (1895).

Selangor, vii.1914, 1 ‥-Peninsular Siam: Nakon Sri Tamarat, Khao Luang, 2,000 ft., iii.iv. 1922 (H.M.P.), 3 ô $\widehat{0}, 2$ 우우.-Known to me also from Perak, Sumatra and Borneo.

5. Mecotropis pardalis Jord. (1913).

Pahang: Lubok Tamang, 3,500 ft., vi.1923 (H.M.P.), 1 ․-—-Described from a single ô labelled Tondano, Minahassa, 7-9, 1899 (collector C), from coll. van de Poll. I do not find any difference between the Pahang $q$ and this $\hat{o}$, apart from sexual distinctions.

\section{Mecocerus pendleburyi sp. nov.}

․ Niger, sparsim griseo-olivaceo tomentosus, manifestissime albo guttatus, fronte capitis carinata.

Long. (cap. excl.) 15-17 mm.

Selangor: The Gap, 2,700 ft., i.1915, 2 우, type-—Pahang: Lubok Tamang, 3,500 ft., vi. 1923 (H.M.P.), 1 ; ; Sungai Renglet, iii. 1925 (H.M.P.), 1 ㅇ.

The species bears a very close resemblance to Meganthribus atopus stellatus subsp. nov., the white spots standing out very conspicuously on the dark ground. The olivaceous pubescence lost in one of the specimens. The number of the white spots fairly constant: on pronotum one in middle and a longitudinal row of three towards side, sometimes an additional basal spot at each side of middle ; on elytra those in third interspace elongate, three to five in fifth, some minute ones in seventh, and three or four along margin, one on suture at base. On underside three spots laterally on prosternum and one between coxae; on mesosternum a spot on central process, another each side anteriorly on neck and an elongate bipartite one on epimerum; on metasternum a central spot and two or three on side, of which one on epimerum ; abdominal segments 1-4 with a lateral spot and a transverse apical median spot more or less divided. Femora with white subapical spot. Segment 7 of antenna white at apex.

This species is a mimetic development of $M$. assimilis Jord. (1895), and comes nearest in appearance to M. assimilis lituratus Jord. (1913) from Tondano, $\mathrm{N}$. Celebes, but is much larger and has entirely black tibiae and tarsi.

7. Mecocerus allectus allectus Pase. (1860).

Peninsular Siam : Nakon Sri Tamarat, Khao Ram, 750-1,200 ft., iii. 1922 (H.M.P.), 1 ㅇ.

8. Mecocerus gazella guttatus Jord. (1895).

A series from Salangor, Perak, and Peninsular Siam ; evidently a common insect.

9. Mecocerus brevipennis Jord. (1895).

Originally described from Borneo; occurs also on the Malay Peninsula and Sumatra.

\section{Physopterus hedistus sp. nov.}

๙. Niger, tomento chocolatino obtectus, parum griseo variegatus, interspatiis alternis elytrorum inconspicue nigro et griseo tessellatis. Frons capitis carinata. Pronotum ante medium atque ante carinam paululo depressum, in medio leviter 
bigibbosum. Elytra breviter oblonga, absque tuberculis et penicillis altis, guttis nigris autem paulum convexis.

Long. 8.6 mm.

Pahang : Fraser's Hill, 4,000 ft., ix.1923 (M. R. Henderson), 1 ô.

Of nearly the same shape as Ph. tuberculatus Jord. (1894), from Ceylon, but the antenna and tarsi much slenderer, the median sulcus of the proboscis much broader, the pronotum and elytra without high tubercles, etc.

Antenna black, the apices of segments 3 to 7 , the whole of 8 and the proximal half of 9 white, 3 a very little shorter than 4 . Proboscis rather abruptly convex between the antenna, from this elevated portion a broadish groove extends obliquely apicad and laterad on each side. Carina of head sharp and rather high between the eyes.

Pronotum one-third broader than long; antemedian transverse depression very distinct, behind it two transverse swellings, but neither tubercles nor tufts present.

Basal margin of elytra more strongly rounded than in $P h$. tuberculatus. Tibiae with a broad basal and a narrower postmedian ring of chocolate and grey pubescence; tarsal segment 1 about as long as 4, basal two-thirds of 1 , extreme base of 2 and middle of 4 white, 2 and 3 much narrower than in $P h$. tuberculatus and 1 longer. Prosternum flattened in middle, the coxae more widely apart than is usual, the anterior intercoxal process obtuse, on a level with the posterior one, with which it is united.

\section{Acorynus rusticus Pasc. (1859).}

Peninsular Siam : Nakon Sri Tamarat, 2,000 ft., iii. 1922 (H.M.P.), a pair.

12. Acorynus frontalis Jord. (1895).

Same locality, 300-750 ft., ii.1922 (H.M.P.), 1 ô.-Perak: Batang Padang, ii.iii.1915, 1 ô.—-Selangor : Sungai Buloh, ix. 1922 (H.M.P.), 1 ㅇ.

13. Anthribus similis bacillosus Jord. (1926).

Selangor : Sinling Bidai (C. B. Kloss), 1 \% ; Gombak Valley, x. 1921 (H.M.P.), 1 ㅇ.

14. Anthribus punctipennis Jord. (1895).

Selangor: Gombak Valley, x.1921, and Peninsular Siam: Nakon Sri Tamarat, Khao Ram, 300-750 ft., ii. 1922 (H.M.P.), 1 ô, 1 ㅇ․

\section{Acorynus coenonus Jord. (1911).}

Perak: Batang Padang, 1800 and 2500 ft., viii.1922, vi.1923 (H.M.P.), and Selangor: Gombak Valley, x.1921 (H.M.P.), 4 ô. ô.

16. Acorynus bicornis Jord. (1826).

Perak : Batang Padang, 1800 ft., vi. 1923 (H.M.P.), 1 q.

17. Acorynus cludus Jord. (1895).

Selangor : Kuala Lumpur, i. 1922 (H.M.P.), 1 $\widehat{\jmath}$. 


\section{Acorynus bimaculatus Kirsch (1875).}

Selangor : Gombak Valley, x.1921 (H.M.P.), 1 ô.

\section{Acorynus phelus Jord. (1926).}

Pahang: Lubok Tamang, 3,500 ft., vi.1923 (H.M.P.), a pair.-In the $\widehat{\sigma}$ the midtibia bears a tooth at the apex, the pygidium is truncate, with the angles rounded, and the anal sternite broadly flattened in middle.

20. Acorynus pictus Pasc. (1860).

A common species, in the F.M.S. Museum from Selangor and Perak.

\section{Acorynus scobis sp. nov.}

1ㅇ. Speciminibus parvis $A$. passerini similis, carinis rostri multo minus manifestis, antennis brevioribus clava compacta, elytris luteo-griseis annulo parvo subbasali, fascia lata dentata mediana, area apicali anguloque humerali brunneis, tibia intermedia maris inermi.

Long. $2 \cdot 3-3 \cdot 2 \mathrm{~mm}$.

Selangor : Kuala Lumpur, ix . 1922, on bamboo hedge, and iii. 1923 (H.M.P.), 2 oิ

Rufous brown, antenna and legs more or less pale rufous. Proboscis shorter than in Acorynus passerinus Pasc. (1859), the lateral earinae less straight and lower, apical margin slightly sinuate in middle. Frons as broad as first segment of antenna in + , narrower in 0 . Antenna of 0 : 3 a little longer than 2, 4 to 8 decreasing in length, 8 less than twice as long as broad, much shorter than 9 , club gradually widening to middle of 11, 9 conical, somewhat longer than broad, 10 broader than long, 11 longer than 9, narrowing to an obtuse point from middle; in $q$ proportions the same. Pronotum as in A. passerinus, but the grey lateral markings smaller and the median markings united into a complete, broadish, median stripe. On elytra an anteriorly open ring, a spot on shoulder angle (in one specimen also an angle-shaped spot obliquely above shoulder), a broad median band, anteriorly tridentate and laterally accompanied by some streaks, and a large apical area enclosing some grey spots brown. Pygidium and anal sternite a little longer in $\widehat{o}$ than in + . First tarsal segment about as long as 2 to 4 together, not longer. Underside of body and the legs uniformly grey, sides of prothorax with a diffuse brown spot, grey pubescence more concentrated on sides of meso- and metasternum. Hypopygidium ( $\hat{\sigma})$ bisinuate, the three lobes short and rounded.

22. Litocerus plagifer Jord. (1897).

Perak: Batang Padang, 1,800 ft., vii. 1923 (H.M.P.), 1 oै.

23. Litocerus miles Jord. (1925).

Selangor : Bukit Kutu, 500-1000 ft., iv. 1926 (H.M.P.), 1 ․

24. Litocerus virgulatus Jord. (1914).

Perak : Batang Padang, 2,500 ft., vi. 1923 (H.M.P.), a pair. 


\section{Litocerus infirmus sp. nov.}

§̊․․ Similis L. mileti Jord. (1925), parvus, pallidus; pronoto griseo-luteo utrinque duabus vittis approximatis brunneis notato; elytris griseo-luteis area magna laterali in medio ad striam tertiam usque extensa brunnea.

Long. $4.5 \mathrm{~mm}$.

(Kuching, Borneo, 1 ô, type.) Peninsular Siam: Nakon Sri Tamarat, Khao Ram, 1,200 ft., ii. 1922 (H.M.P.), 1 ㅇ.

Antenna of o nearly as in L. histrio Gylh. (1833), broadened from segment 5 , and these compressed segments nearly alike, 2 short, 3 slightly longer than 4 ; in 93 one-third longer than 4,8 less than two-thirds 9,9 to 11 decreasing in length. Of the two brown stripes on each side of the pronotum the inner one reaches from base to apex, the outer one is shortened anteriorly and here somewhat dilated sidewards, the two stripes touch each other (or nearly) behind middle. The brown lateral area of the elytrum is widest at side, narrowing dorsad and reaching to the third interspace, there being a small dash between it and suture, at lateral margin the area extends along margin to shoulder and is posteriorly broadly connected with a transverse anteapical brown band; in front of this band a narrow zigzag band in type, whereas in $q$ the zigzag band is merged together with the subapical band, forming a large patch; in the brown lateral area some grey spots ; near base in grey area a few brown markings, the most conspicuous ones being a dot on subbasal swelling and a line in fourth interspace.

Underside unspotted. Legs very pale rufous, incrassate portion of femora partly blackish.

26. Tropideres paviei Lesne (1891).

Pahang : Kuala Tahan, 300 ft., xi. 1921 (H.M.P.), 1 ㅇ.

27. Tropideres securus Boh. (1839).

As before, $1 \hat{\jmath}$; another from Kuala Lumpur.

28. Cedus camelinus Jord. (1915).

Pahang: Kuala Tembeling, at light, ii.1923 (H.M.P.), 1 ô.

\section{Sympaector vittifrons Kirsch (1875).}

Pahan: Kuala Teku, 300 ft., xii.1921 (H.M.P.), 1 ô; and Peninsular Siam : Nakon Sri Tamarat, Khao Luang, 2,000 ft., iii.1922 (H.M.P.), 1 ๙ิ.

30. Sympaector pagis ligyrus Jord. (1911).

Perak: Maxwell's Hill, 3,000 ft., vi. vii.1916, 1 ㅇ.-Described from a single of from "Malacca." The $q$ agrees with the $\hat{\sigma}$ apart from the sexual distinctions.

\section{Xenognathus gen. nov.}

o. Generis Cedus Pasc. (1860) dicti affinis, mandibulis longis angustis porrectis facile distinguendus.

Genotype: $X$. pellitus sp. nov.

The long and narrow mandibles, with two minute teeth on inner margin and curving towards each other at apex, recall those of the larva of an ant-lion. 
Upperlip longer than broad, truncate, bisinuate, the lateral angles pointed, the median one very short, obtuse. Sinus of labiophore broadly triangular; the underlip divided to near insertion of palpi into two very narrow pointed lobes; the labial palpus long and very slender. Rostrum truncate, the angles rounded off and distinctly receding, in basal half traces of three carinae. The lateral curve of the prothoracic carina less wide than in $C s d u s$, the longitudinal basal carinula descending. Otherwise the new genus similar to Cedus, apart from colour, in which the only known specimen agrees better with some small rufous species of Mecocerina Jord. (1894).

\section{Xenognathus pellitus sp. nov.}

๙. Brunneus, supra cruce prothoracicali atque vitta suturali utrimque trilobata luteo-griseis ornatus, subtus pallide rufus, griseo pubescens.

Long. $4 \cdot 3 \mathrm{~mm}$.

Pahang: Sungai Takar, ix. 1922 (H.M.P.), 1 ô.

Proboscis one-fifth broader at apex than long, with a slight swelling each side between the antennae, apical half flat. Mandibles, measured from middle of apex of rostrum, a little over two-thirds the length of the rostrum. Frons slightly narrower than first segment of antenna. Occiput brown in middle. Antenna more than twice as long as the body, segments 3 to 11 long, 8 to 11 decreasing in lengths, 11 being shorter than 10, as in C. guttatus Pase. (1860).

Pronotum one-half broader than long, with a broadish median stripe, to which is joined each side a spot placed in the transverse sulcus, the grey pubescence extending along carina as a narrow border, towards side a subapical, a median, and a basal spot, the lateral carina broadly bordered with grey, the transverse antemedian furrow angulate in middle, each half anteriorly convex; dorsal carina nearly straight, slightly convex; sides and posterior brown discal area punctate. Scutellum subcircular, luteous grey.

Elytra half as long again as broad, subcylindrical, somewhat impressed behind the feebly elevate subbasal swelling, strongly punctate-striate, the sutural luteous grey marking (on a rufous ground) somewhat resembles the flattened out skin of a mammal, the stripe covers about two and one half interspaces, but widens out three times : once at basal margin, extending here halfway to shoulder, then again in antemedian depression, this branch reaching to interspace 7, the postmedian branch nearly extends to margin, the " tail " almost separated from "body-skin," longitudinally divided, curving sideways, a small spot above shoulder at base, another behind shoulder, a longer diffuse limbal one at shoulder, an antemedian limbal spot and another obliquely above and behind it also grey; suture slightly brown behind middle. Pygidium somewhat broader than long, rounded.

Middle of prosternum densely, sides of pro- and mesosterna dispersedly punctate, abdomen impunctate. Legs long, pale rufous, upperside of tibiae and tarsi slightly brownish, first tarsal segment two to three times as long as the other segments together.

32. Habrissus heros Pasc. (1871).

Gunong Tahan, 3,300 ft., xi.1920 (J. Bragga), 1 ․- The first specimen I have seen from the Malay Peninsula. 
33. Nessiara longicollis Jord. (1911).

Selangor : Kuala Kubu, Bukit Kutu, 3,400 ft., viii.1915, 1 ․-—Peninsular Siam : Nakon Sri Tamarat, Khao Luang, 2000-2500 ft., iii. 1922 (H.M.P.), 3 우.

34. Sintor bicallosus Lac. (1866).

Pahang: Cameron's Highlands, 4800 ft., Oct. 1923, at light (H.M.P.), and Lubok Tamang, 3,500 ft., vi. 1923 (H.M.P.), 2 ô.

35. Sintor quadrilineatus Fahrs. (1839).

Perak: Jor Camp, 2,000 ft., viii. 1922 (E. Seimund), 1 ㅇ.

36. Sintor guttatus Kirsch (1875).

Pahang: Cameron's Highlands, 4,800 ft., vi. 1923 (H.M.P.), 1 ô.

37. Sintor rhabdotus Jord. (1923).

Peninsular Siam: Nakon Sri Tamarat, Khao Ram, 1500-3000 ft., iii.1922 (H.M.P.), 1 ô, 1 ㅇ.

38. Cleorisintor glaucus Jord. (1923).

Selangor : Kuala Lumpur, vi.1921 (H.M.P.), 1 ㅇ.

39. Xenocerus deletus Pasc. (1860).

Perak (C. Wray), 2 우.—Pahang: Sungai Renglet, 3,500 ft., iii.1925 (H.M.P.), 1 ô-Peninsular Siam : Nakon Sri Tamarat, Khao Luang, 2,000 ft., iii. 1922 (H.M.P.), 1 ऽิ, 3 우.

40. Xenocerus variabilis Pasc. (1860).

Perak: Maxwell's Hill, 3,000 ft., vi.vii.1916, 1 o.- Selangor: Kuala Lumpur, 1 ô ; Rawang, vii.1914, 2 ડิ oิ ; Bukit Kutu, 3,000 ft., iv. 1926 (H.M.P.), 1 ㅇ.

41. Xenocerus fimbriatus Pasc. (1860).

Pahang: Kuala Teku, 550 ft., x.1921 (H.M.P.), 1 ㅇ.

42. Xenocerus pictus Kirsch (1875).

Selangor: Kuala Lumpur, 2 우; Bukit Kutu, v.1909, 1 우 ; The Gap, 2,700 ft., i.1915, 2 ô ô.—Kedah Peak, 4,000 ft., x. 1915, 1 ㅇ․

43. Xenocerus saperdoides Gylh. (1839).

Selangor: Kuala Kubu, Bukit Kutu, 3,400 ft., viii.1915, 1 q.—Kedah Peak, x.1915, 1 우.

44. Xenocerus tephrus Jord. (1913).

Perak (C. Wray), 1 ô, 2 웅- Selangor : Kuala Lumpur, 2 우 ; The Gap, 2,700 ft., i.1915, 1 \&; Kuala Kubu, Bukit Kutu, 3,400 ft., viii.1915, 1 ㅇ.Pahang: Cameron's Highlands, Tanah Ratu, 4,800 ft., i.1924, at light (M. R. Henderson), and in same district, 4,800 ft., x. 1923 (H.M.P.), 1 §ิ우 ; Sungai Renglet, 
3,500 ft., iii. 1915 (H.M.P.), 4 우, some at light; Gunong Padang, 5,500 ft., xii. 1923 (H.M.P.), 1 q ; Lubok Tamang, 3,500 ft., vi.1923, at light (H.M.P.), 1 ô. - The species was described from a single ô from Perak, and no further specimens had come to hand until Mr. Pendlebury sent the above series. The pronotum and elytra are uniformly grey (apart from dark spots due to abrasion), but in one $q$ there is a remnant of the ancestral pattern, the elytra bearing in this example a minute brown postmedian dot on second line of punctures and farther back in sutural interspace a short thin brown line. The head has usually a brown median stripe and varies from yellow to nearly white. The antenna of the $q$ varies much in colour, the principal varieties being: $(a)$ segments 1 to 8 yellowish grey; $(b)$ segments 5 and 6 bluish black; and $(c)$ all segments bluish black. Similar colour-variations occur in other species with hairy of antennae, for instance $X$. saperdoides and $X$. pictus.

45. Stiboderes cavifer Jord. (1925).

Selangor: The Gap, 2,700 ft., i.1915, 1 o.-Known to me from Java, Sumatra, Borneo, Luzon, and North Celebes.

46. Stiboderes chevrolati Rits. (1883).

Perak : Batang Padang, 1,800 ft., i. 1925 (H.M.P.), 1 q.

47. Taphrodes marmoratus Roel. (1880).

Pahang: Sungai Renglet, 3,500 ft., iii. 1925 (H.M.P.), 1 ․-Peninsular Siam : Nakon Sri Tamarat, Khao Luang, 2,000 ft., iii.iv. 1922 (H.M.P.), 1 ô at light, 1 \%.

48. Xylinades rugosus carbo subsp. nov.

수. Capitis carina media angustior.

Pahang: Cameron's Highlands, 4,800 ft., x.1923 (H.M.P.), 2 oิ ô, type ; ibid., i.1924 (M. R. Henderson), 1 ô ; Sungai Renglet, 3,500 ft., iii. 1925 at light (H.M.P.), 1 o.—Perak : Batang Padang, 1,800 ft., vi.1923, at light (H.M.P.), 1 오.

In $X . r$ rugosus Gylh. (1833), from Java, the median carina of the head is broadish and therefore appears less convex than in X.r. carbo ; it is also longer in the specimens from the Malay Peninsula.

49. Xylinades aruensis Jord. (1895).

Selangor: Gombak Valley, x.1921 (H.M.P.), 1 ô; and Pahang: Sungai Renglet, 3,500 ft., iii.1925, at light (H.M.P.), 1 ㅇ.

50. Xylinades nodicornis Weber (1801).

Perak : Batang Padang, 1,800 ft., i. 1925, at light (H.M.P.), 1 ô.

51. Dendrotrogus perfolicornis F. (1801).

Pahang: Lubok Tamang, 3,500 ft., vi.1923 (H.M.P.), 1 의 and Peninsular Siam : Nakon Sri Tamarat, Khao Luang, 2,000 ft., iii. 1922 (H.M.P.), 1 ․ 
52. Dendrotrogus hypocrita Jekel (1855).

A common species, widely distributed.

53. Eucorynus crassicornis F. (1801).

Evidently everywhere in Indo-Malayan countries.

54. Rawasia ritsemae Roel. (1880).

Perak: Batang Padang, 1,800 ft., iii. 1924 (H.M.P.), $1 \hat{\jmath}$.

55. Rawasia annulipes Jord. (1895).

Perak: as above, v.1923 (H.M.P.), 1 ô, and Selangor: Gombak Valley, viii. 1822 (H.M.P.), 1 ․

56. Rawasia communis robusta subsp. nov.

๙. Major, pronoto lateribus minus rotundato, elytris brevioribus, tibiis apice nigris.

Long. 12-14 mm., lat. 5-6 mm.

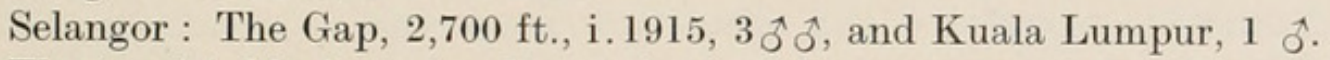

Elytra with black postmedian tuft as in R. c. communis Jord. (1895), from Assam. Prothorax more conical than in the Assamese subspecies, the elytra shorter, less cylindrical. Apex of mid- and hindtibiae more extended black (in foretibia the apex black on underside only).

57. Caccorhinus obscurus Jord. (1904).

Lobok Kedondong, N.W. of Mt. Ophir, 200 ft., xi.1920 (H. C. Abraham), 1 q.

58. Basitropis rotundata Jord.

Tamarat, Khao Luang, 2,000 ft., iii.1922 (H.M.P.), 1 ㅇ.

59. Basitropis platypus Jord. (1903).

Selangor : Gombak Valley, x.1921 (H.M.P.), 1 q.——Only a few specimens of this broad-footed species are known to me.

60. Phloeobius alternans Wied. (1819).

Perak: Batang Padang, 1,800 ft., v.1923 (H.M.P.), 1 ô, 1 †; same place, vi.1924, at light (H. R. Henderson), 1 우.

61. Ozotomerus rugicollis Jord. (1895).

Selangor: Kuala Lumpur, vi.1916, 1 ô-_-Pahang: Kuala Tahan, xi.1921 (H.M.P.), 1 â-_-Peninsular Siam : Nakon Sri Tamarat, Khao Ram, $750 \mathrm{ft}$., ii. 1922, at light (H.M.P.), 1 ㅇ.

62. Apolecta aspericollis Kirsch (1875).

Pahang (W. H. D. Edwards), 1 ô; Pahang: Senyum, Kotu Tongkat, vi. vii. 1917, 1 ㅇ. 
63. Apolecta latipennis Jord. (1916).

Pahang: Sungai Renglet, $3800 \mathrm{ft}$., iii.1925, at light (H.M.P.), $1 \hat{\jmath}$, and Fraser's Hill, 3500-4500 ft., viii.1923 (H.M.P.), 1 ô.-These $\hat{o} \widehat{o}$ are less broad in the elytra than the of from which the species was described, but agree otherwise very well with it.

64. Apolecta puncticollis Jord. (1895).

Perak (C. Wray), 1 ô.—Pahang: Kuala Tahan, 300 ft., xi.1921 (H.M.P.), 1 ㅇ.

65. Araecerus fasciculatus Deg. (1775).

Selangor : Kuala Lumpur, i., iv., vi., x., a series, one ô at light.

66. Araecerus corporaali Jord. (1924).

Selangor : Kuala Lumpur, viii. 1922 (H.M.P.). 1 ㅇ. 


\section{$2 \mathrm{BHL}$ Biodiversity Heritage Library}

1928. "Anthribidae from the Malay Peninsula." Novitates zoologicae : a journal of zoology in connection with the Tring Museum 34, 95-104. https://doi.org/10.5962/bhl.part.11787.

View This Item Online: $\underline{\text { https://www.biodiversitylibrary.org/item/23229 }}$

DOI: https://doi.org/10.5962/bhl.part.11787

Permalink: https://www.biodiversitylibrary.org/partpdf/11787

\section{Holding Institution}

Natural History Museum Library, London

\section{Sponsored by}

Natural History Museum Library, London

\section{Copyright \& Reuse}

Copyright Status: In copyright. Digitized with the permission of the rights holder.

Rights Holder: The Trustees of the Natural History Museum, London

License: http://creativecommons.org/licenses/by-nc-sa/4.0/

Rights: http://biodiversitylibrary.org/permissions

This document was created from content at the Biodiversity Heritage Library, the world's largest open access digital library for biodiversity literature and archives. Visit BHL at https://www.biodiversitylibrary.org. 